\title{
PERSONAL INJURY LITIGATION.
}

A writer in the North American Revieze of February, r897, has performed a public service by calling attention to the enormous increase of actions claiming damages for personal injuries or for death resulting therefrom. Crude and limited as are the statistics he gives enough is shown to startle the ordinary reader who is not familiar with the subject. Yet there are considerations not adverted to by him which are quite as interesting to one seriously thinking out some remedy for an obvious evil. That evil is the corrupted public sentiment in favor of looting any public or quasi-public treasury in aid of private suffering or private want, if not private greed. Its expression is not confined to the jury-box nor to personal injury verdicts. It appears in constitutional conventions, legislatures and in Congress.

Its operation is sometimes bold, as in pension legislation of high and low degree, appropriations for private benefit under the disguise of public needs, in many forms, and in all kinds of legislation to make this species of pillage easy by removing whatever barriers are found in the ancient law and the repugnance of our ancestors; and sometimes it is more insidious and crafty, as in proposed reforms of practice which have the purpose of ousting the bench from all power to hinder the plundering process. If a legislator wishes by statute to direct how the judge shall instruct the jury generally you will find in him or those who are behind bim the speculators, runners and brokers in damages for personal injuries mentioned by the writer in the North American Review.

Nor is it strange that men coming into the jury-box from the flood tides of a periodical literature devoted to an agitation for relief from individual suffering by socialistic combinations of the poor against the rich, should find the verdict of a jury against "a corporation" a most convenient sort of combination to mitigate the suffering at least in this one case. Are not all corporations a trust organized by capital to oppress labor? And this being so is not the denial by this corporation of its liability to this plaintiff a part of the conspiracy of the rich to oppress 
the poor? It will only "average up things" if we take every occasion to distribute some of this dangerous aggregation of wealth to those who sorely need it, and the "corporation" will never feel the loss. Perhaps not a single juryman is conscious of this reasoning in the given instance of its exercise; indeed, he does not, in fact, go through this formula in reaching his verdict and is, therefore, not guilty of the implied corruption there is in it; nevertheless, his state of mind is such that the process works itself by the callous indifference he indulges towards the case of the "corporation," and the supersensitive sympathy he feels towards a poor laborer or anyone injured by violence, causes him to do an injustice he does not recognize as such. But this state of mind is chronic with him and the result of a pernicious education. The strong men who resist or resent any influence of this kind are not generally found in the jury-box.

Nor is there wanting a very considerable justification for a good deal of this ill feeling towards railroads, mostly the victims of personal-injury verdicts, arising out of their own conduct in the premises. Almost without exception everywhere they adopt the policy of "fighting" every claimant for damages, no matter how clear their liability, unless it may be they will "compromise" when they can pay a nominal and wholly inadequate sum; they ridiculousiy search the injured man's smallest actions with hypercritical minuteness for some trace of contributory negligence and in directions that they must know are unjust, because the conduct complained of is in their own interest or with generous fidelity was supposed by the employee to be so, or else was taken with a human thoughtlessness in those engaged in earnest and faithful labor that is practically unavoidable; they even make rules that they know cannot be enforced, such as that a brakeman shall never go between moving cars to couple or uncouple them when it is certain that under some circumstances the cars cannot be coupled unless they are moving, and when they know that a want of courage in this respect would result in dismissal because it would be in fact inefficiency; doing this in order that the rules may be used in stress of weather as a harbor of refuge-a pretext for a counter-claim of contributory negligence; they even send their "runners," in the shape of claim agents, local lawyers, doctors, surgeons and nurses, to take "statements" that are, to say the least, if not perverted to suit their interests, with great injustice made to speak most favorably for the company, and these are sometimes used as impeaching testimony under circumstances that shock the commonest sense of humanity; as in one case 
where the amputation was delayed after the ether had been partially administered until the "statement" could be taken, amid protests from the by-standers that it was not fair; and so there often appear many evidences of injustice on the part of the companies that jurors are quick to notice and resent, resulting in a general prejudice against the companies that makes verdicts against them all too easy.

Again, in the struggle against the well-founded belief that it is almost impossible to have juries do right towards the defendants in personal injury cases, there is a possibility of "straining the timbers of the law" and pressing perilously near the danger line in rulings upon contributory negligence, fellow-servant law and the like defenses, and in directing the verdicts of juries. He need not be a very old lawyer to know that to send up to an appellate court a bill of exceptions containing all the testimony was until recently almost unknown in any well-regulated jurisdiction; the Supreme Court of the United States for a hundred years forbade it because under our Federal Constitution an appellate court cannot have the jurisdiction to re-try a question of fact. Yet, nowadays, the feeblest whisperings and the most inconsequential givings out of all the witnesses must go up that the appellate court may say whether the case ought to have been submitted to the jury or ought not to have been so submitted, and whether the trial judge should not have directed the verdict always asked of him by the railroad company, as if there never were a case when it should not be done; certainly it is never admitted by the railroad lawyer that a case against a railroad company can be one for the jury; if he grants this motion the railroad company feels that it has escaped the peril of the jurybox; if he refuses, it feels that there is another chance that other judges may save it that peril. And so there beat about the constitutional guaranty of trial by jury strong forces whose activities are dangerous beyond all question.

It is mostly this personal injury litigation that has developed so actively the practice of directing verdicts by the court. That the power exists there can be and never was any question, but that it was for a long time, and until this evil of jury injustice to railroads invoked it, almost dormant in this country is also true. It stands in the way of personal-injury speculators and lawyers, and they are engaged everywhere in every way in hostile array against it-saying that the judgment of judges whether railroad companies shall pay damages is not more to be trusted than the verdict of juries, and here we have 
in the struggle against the practice of directing verdicts another startling effect of the growth of personal-injury litigation as shown by the article in the North American Review.

Nor is this all, for in the Constitutional Conventions and Legislatures the influences hostile to the railroad companies are assiduously engaged in digging out and casting away almost every vestige of the law of contributory negligence, of fellow servant, of defective machinery known to be so, and like defenses, and turning these companies into delightful accident and life insurance companies, with no fine-print restrictions and without premiums for the risks, except such as they levy on the public by increase of transportation rates in their schedules.

Shall we loosen or abandon the guaranty of trial by jury, abrogate all just protection to the master as against claims of compensation for an injury to his servant while in his service and all laws protecting railroads in the rightful use of their tracks as against trespassers and those using the crossings, merely because jurors will not do the right thing towards "corporations," and because there are so many cormorants' and their trainers interested in having them levy contributions on corporation treasuries in aid of the suffering poor? No. It is not essential to do any of these things, but it is necessary that public opinion-that great corrector of all social evils-shall be aroused and educated to the right way of thinking on this subject. The railroad companies can help by doing right themselves and paying without litigation every just claim. If they would organize in their own legal department "a court" to which the claimant might himseli resort if he found it fair to him, and which at all events would make a perfectly impartial investigation in all cases, and whenever the claim was just fix the reasonable compensation which the law itself would give, tendering this without litigation, the prejudice against them in the jury-box might almost disappear and then the juries would make short work of the speculators in unjust and fabricated claims. Many companies might combine to maintain such a tribunal, and as an adjunct to it organize for a uniform and systematic defense against wrongful claims, tendering the money into court in all that were fair and honest when the offer of compensation should be rejected. Such a plan as this may not. be practicable but if it be it is worth a trial to check the evil tendencies of that now in use. It would require big lawyers to sustain it but big lawyers are at the service of corporations to meet this demand. Compulsory arbitration by statutory meth- 
ods would afford no better tribunals than existing courts, but the voluntary offer to pay fair demands for injuries sustained would soon do its work of restoring a sense of justice in the jurybox. The work cannot all be done by the bench.

It is a long jump from 4 Edw. III., C. 7, which abrogated the rule that personal actions die with the person even as to injuries to property to Lord Campbell's Act, giving an action for the wrongful killing of another to those who suffer by the death; but this space of time and growth in legal remedies has witnessed a corresponding enlargement of the importance of the law of torts. If people are more civilized they are less inclined to submit to injuries that entail pecuniary loss when they can obtain redress, not by retaliation in kind, but by a kind of recoupment in money damages. Love of money and love of the remotest and most questionable chances to get it have grown with the civilization we boast and there is nowhere a more disagreeable exhibition of it than the uses made of slight wrongs or injuries that ordinarily were never noticed hitherto, but now are made the foundation for building up by perjury, and all the arts and devices of sharp practice, claims for enormous damages. The sharp practices of two professions, legal and medical, are called in to aid the money-raid upon the unfortunate tort-feasor. The personal-injury lawyer and the personal-injury doctor, with his "traumatic neurosis," stand in the ring and fight the railroad doctor and the railroad lawyer, with his "contributory negligence," from "start to finish" with a jury for the referee and a judge who is reduced by legislation, if possible, to be a mere official time-keeper. The "Marquis of Queensberry rules" provided by constitutional conventions and Legislatures are all onesided and in favor of the Plaintiff. The comparisons for ferocity now raging between the prize-ring and the college foot-ball game should not ignore the combat between the "Master and Servant" in a personal injury case in a court of law.

Eli Shelby Hammond. 